\title{
Determinants, benefits and barriers of informal learning in the Netherlands
}

Citation for published version (APA):

Caniëls, M., \& Kirschner, P. A. (2012). Determinants, benefits and barriers of informal learning in the Netherlands. In P. van den Bossche, W. H. Gijselaers, \& R. G. Milter (Eds.), Learning at the crossroads of theory and practice: Research on innovative learning practices (Vol. 4, pp. 93-110). Springer Business and Media. Advances in Business Education and Training Vol. 4

Document status and date:

Published: 01/01/2012

Document Version:

Peer reviewed version

Please check the document version of this publication:

- A submitted manuscript is the version of the article upon submission and before peer-review. There can be important differences between the submitted version and the official published version of record. People interested in the research are advised to contact the author for the final version of the publication, or visit the DOI to the publisher's website.

- The final author version and the galley proof are versions of the publication after peer review.

- The final published version features the final layout of the paper including the volume, issue and page numbers.

Link to publication

\section{General rights}

Copyright and moral rights for the publications made accessible in the public portal are retained by the authors and/or other copyright owners and it is a condition of accessing publications that users recognise and abide by the legal requirements associated with these rights.

- Users may download and print one copy of any publication from the public portal for the purpose of private study or research.

- You may not further distribute the material or use it for any profit-making activity or commercial gain

- You may freely distribute the URL identifying the publication in the public portal.

If the publication is distributed under the terms of Article $25 f a$ of the Dutch Copyright Act, indicated by the "Taverne" license above, please follow below link for the End User Agreement:

https://www.ou.nl/taverne-agreement

Take down policy

If you believe that this document breaches copyright please contact us at:

pure-support@ou.nl

providing details and we will investigate your claim.

Downloaded from https://research.ou.nl/ on date: 26 Apr. 2023 


\section{Advances in Business Education and Training}

Volume 4

\section{Series Editor:}

Piet Van den Bossche, Department of Educational Research and Development,

Faculty of Economics and Business Administration, Maastricht University, the

Netherlands

Institute for Education and Information Sciences, University of Antwerp, Belgium

\section{Associate Editors}

Wim Gijselaers, Department of Educational Research and Development, Faculty of Economics and Business Administration, Maastricht University, the Netherlands Richard G. Milter, Carey Business School, Johns Hopkins University, USA

\section{Scope of the series}

Advances in Business Education \& Training is a Book Series to foster advancement in in the field of Business Education and Training. It serves as an international forum for scholarly and state-of-the-art research and development into all aspects of Business Education and Training. It will not only publish empirical studies but also stimulate theoretical discussions and address practical implications. Also reviews of important developments in the field are encouraged. The editors welcome contributions in which a line of reasoning is illustrated with experiments, design-based studies, best practices, and theory development. In addition, the editors encourage submission of new ideas for business education and training, papers that are not necessarily empirical in nature, but describe interesting new educational tools, approaches or solutions.

The book series will include both edited volumes comprised of peer-reviewed articles as authored books. Each volume is dedicated to a specific theme in business education, and will be complemented with articles that can be a resource to advance business education and training.
Piet Van den Bossche • Wim H. Gijselaers • Richard G. Milter

Editors

\section{Learning at the Crossroads of Theory and Practice}

Research on Innovative Learning Practices

\section{Springer}


Michaelsen Larry K.

Morin Danielle

Niemantsverdriet S.

Nijhuis Jan

Palonen Tuire

Poggi Ambra

Raemdonk Isabel

Ramoorthy Nagarajan

Ravn Jakob

Reeb-Gruber Sandr
Rehm Martin

Rienties Bar

Roth Wolff-Michae

Semeyn, Judith H.

Tempelaar Dirk

Thijssen 'Thoma

Thompson Lindsay J.

Tillema Harm

van Loo Jasper

\section{Contents}

Piet Van den Bossche (Series editor)

Wim Gijselaers and Rick Milter (Associate series editors)
1 Learning at the Crossroads of Theory and Practice: An Overview ... Piet Van den Bossche, Wim H. Gijselaers and Richard G. Milter

Part I Integrating Theory and Practice in Business Education

2 Enhancing the Academic Internship Learning Experience for Business Education-A Critical Review and Future Directions ... Maike Gerken, Bart Rienties, Bas Giesbers and Karen D. Könings

3 Combining Formal and Non-formal Learning for Undergraduate Management Students Based in London .................... Martin Rich and Ann Brown

4 Work-Based Learning Versus Work-Related Learning-An Exploration of the Possibilities of Work-Related Learning Through a Review of the Venture Matrix at Sheffield Hallam

University, UK David Laughton

Part II Workplace Learning

5 What Keeps Low- and High-Qualified Workers Competitive: Exploring the Influence of Job Characteristics and Self-Directed Learning Orientation on Work-Related Learning David Gijbels, Isabel Raemdonck, Dries Vervecken and Jonas Van Herck

6 The Use of Personal Development Plans (PDPs) in Organization and the Role of Its Perceived Purpose Nina Ketels, Simon Beausaert and Mien Segers

7 Determinants, Benefits and Barriers of Informal Learning in The Netherlands

Marjolein C.J. Caniëls and Paul Kirschner 
Snyder, J., Pippincott, A., \& Bower, D. (1998). The inherent tensions in the multiple use of portfolios in teacher education. Teacher Education Quarterly, 25(1), 45-60.

Sobel, M. E. (1982). Asymptotic intervals for indirect effects in structural equation models. In: S. Leinhart (Ed.), Social methodology 1982 (290-312). San Francisco: Jossey Bass.

found Tillema. H. H. (1998) Decing profssional develophent. Social Work Education, 18, 147-160.

in Eduction

Tillema, H. H. (2001). Portfolios as developmental assessment tools. International Journal of Wade, R. C. \& Yarbrough, D. B. (1996). Port

. Portfolios: A tool for reflective thinking in teacher education. Teaching and Teacher Education, 12(1), 63-79.

School \&eaderhip. (1998). Professionalism, portfolios and the development of school leaders. School Leadership and Management, $18(1), 123-140$.

portfolios for assessment of the competence and performance of doctors in practice. Medical Education, 36, 918-924.

(teaces Welf $K$, \& Diez, M. (1998).

Quart, \&ietz, M. (1998). Teaching portfolios: Purposes and possibilities. Teacher Educational

Wright, W. A., Knight, P. T., \& Pomerleau, N. (1999). Portfolio people: Teaching and learning dossiers and the future of higher education. Innovative Higher Education, 24(2), 89-102.

electronics industry in Shenzhetween organizational factors and the transfer of training in the Zeichner, K \& Wray in Shenzhen, China. Human Resource Development Quarterly; 7, 55-72. we know and what we need to know. Teaching and Teacher Education, 17, 613-621.
Chapter 7

\section{Determinants, Benefits and Barriers of Informal Learning in The Netherlands}

Marjolein C.J. Caniëls and Paul Kirschner

\section{Introduction}

Lifelong learning (LLL) has long been taken for granted as being essential for all people and thus as something that will "happen", the idea being that people themselves would make the effort to continue to learn. Where attention was paid to LLL, it was usually through continuing education programmes at universities or private organisations specialised in developing and delivering courses. Noteworthy is that most initiatives saw LLL as formal learning (e.g. an extension of initial formal education). Only recently has LLL become a focal point of Dutch and European policy in relation to innovation, economic growth and social-cohesion, often in conjunction with the perceived need to transform production workers into knowledge workers (CEDEFOP 2009). With this focus, there has also been a broadening of the scope from formal lifelong education to informal LLL. Emphasising the importance of making informal learning visible and valuable is increasingly seen by government bodies as a way to expand LLL. Informal learning takes place outside formal education and training institutions. It encompasses all learning activities that are not formally organised, including learning at work, in leisure time and at home. Informal learning at the workplace includes, for example, on-the-job learning, working alongside more experienced colleagues (i.e. apprenticeship; Bines 1992), working as part of a team and learning from customers, clients and suppliers (Cheetham and Chivers 2000, 2001)

M.C.J. Caniëls (区)

Netherlands Laboratory for Lifelong Learning (NeLLL) \& Faculty of Management Sciences, Open University of the Netherlands, P.O. Box 2960,6401 Heerlen, The Netherlands e-mail: marjolein.caniels@ou.n]

P. Kirschner

Netherlands Laboratory for Lifelong Learning (NeLLL) \& Centre for Learning Sciences and Technologies (CELSTEC), Open University of the Netherlands, P.O. Box 2960, 6401 Heerlen, The Netherlands

e-mail:paul kirschnereoun 
However, before decisions can be made and policy guidelines can be specified on how to use and value informal learning, we must know how much informal learning is actually being undertaken by individuals and what possible barriers exis to participation. In several countries this challenge has been taken up, with as notable example the study by Cheetham and Chivers $(2000,2001) i$ 80 practitioners from 20 professions were interviewed, and a questionnaire survey was distributed among 372 practitioners from six professions. They found that on the job learning was rated by respondents as the most important type of informal learning, followed by learning alongside more experienced others and working as part of a team. The types of job environment that were found to be most conducive to professional development were environments in which people were allowed the freedom to find their own ways of doing things and develop their own professional style, while help was made available if and when needed. Respondents reported the need for a balance between on the one hand being offered support when needed and on the other hand being allowed to do things on their own and make mistakes. Cheetham and Chivers $(2000,2001)$ concentrated on informal learning of professionals in their working environments (i.e. on-the-job) and not whether and how individuals learn outside of the working environment as well.

A study that did incorporate informal learning outside the job is the Work and Lifelong Learning (WALL) survey that was carried out in Canada by the Centre for the Study of Education and Work at Ontario Institute for Studies in Education at the University of Toronto (OISE/UT) in collaboration with the Research Network on New Approaches to Lifelong Learning (NALL). The WALL survey was conducted in 1998 and 2004 among a large representative national sample of 9,063 adult (18+) Canadians (Livingstone 1999; Livingstone and Stowe 2007). A notable finding was that those who are not taking adult education courses are still very likely to participate continually in job-related informal learning. Furthermore, most respondents saw course-based education and informal learning as complementary. Moreover, older workers (i.e. older than 55) stopped taking part in course-based learning almost completely, while their informal job-related learning only marginally declined.

In the study described in this contribution, we choose the Netherlands as focus because it is a country where informal learning is a widely accepted mode of learning. For example, while most universities and polytechnics require a high school diploma for admission (the Open University of the Netherlands is an exception), it is possible for institutions of higher education to acknowledge informal learning in the admission of first year students (Hagens et al. 2007, p. 8). In 1994, the Ministry of Education, Culture and Science published a study titled "Recognising informal skills". In the report, a series of measures and activities were proposed that were aimed at boosting the employability of the labour force, which included measures specifically aimed at enhancing informal learning.

While there are data in the Netherlands on participation in formal LLL (i.e. adult education courses), there has been little reliable research on the fuller extent of Dutch engagement in LLL (i.e. informal learning), and on whether this learning is being used to its fullest potential in paid jobs and beyond. The aim of this research is to probe the Dutch population's perception of key dimensions of paid and unpaid work and of their learning practices. We address the following three basic research questions:
1. What is the relationship between time spent on informal learning by employees and (a) age, (b) level of education, (c) number of working hours per week?

2. What is the relationship between time spent on informal learning by employees and outcome measures, including subjective career success and occupational expertise?

3. What barriers do Dutch adults perceive that keep them from engaging in informal learning?

This contribution presents data from an on-line survey which yielded 520 qualified responses from Dutch citizens between 18 and 64 years old. The analysis is based on descriptive statistics and non-parametric tests.

In this chapter we first present a review of the literature on LLL concepts and research. In the second section, we formulate several hypotheses about factors related to informal LLL and show the current state of affairs of LLL in the Netherlands along these lines. In the subsequent section, we elaborate on our research design and the methodology used. This is followed by the results. Finally we present a conclusion and a discussion of our findings.

\section{Literature Review}

LLL is "... all purposeful learning activity, undertaken on an ongoing basis with the aim of improving knowledge, skills and competence" (Commission of the European Communities 2000, p. 3). This concept is not new. LLL became a worldwide topic of discussion in the 1970s with the publication of a report by UNESCO which called for lifelong education as part of cultural and personal growth (Faure et al. 1972). The Organisation for Economic Cooperation and Development reconceptualised LLL by making it a part of the human capital theory (Field 2001). The European Union gave LLL central prominence as part of the human capital requirements of the knowledge economy and presented it as a key factor for the international competitiveness of European businesses and industry (Commission of the European Communities 2000).

LLL, thus, is increasingly seen as central to the human capital requirements of our ever-developing knowledge economy and a key factor in maintaining the international competitiveness of Dutch and European business and industry. This is due to the fact that much valuable and non-trivial learning takes place outside formal programmes of instruction. Individuals learn and profit from experience in both formal educational settings (e.g. continuing education, in-house training) and informal settings (e $g$. onthe-job/workplace learning and/or learning from media, museums). As such, LLL is an effect of external and internal conditions to individuals, and it has effects on an an effect of external and internal conditions
individual's professional and personal life.

Traditionally, LLL is divided into formal learning and informal learning (for an excellent discussion of this see Van Merriënboer et al. 2009). Formal learning-as related to LLL-is traditionally an extension of formal schooling which Livingstone (1999) defines as an "age-graded, hierarchically organized, formally constituted system... [with] credentialing programmes to certify one's knowledge competencies for starting one's adult lives" (p. 50). The Cedefop glossary (Tissot 2000, 2004) 
notes that it consists of learning that occurs within an "organized and structured context (formal education, in-company training), and that is designed as learning" (Tissot 2000, p. 22). Formal LLL courses and programmes are most often offered by traditional (or new) educational or training institutions and when extended into the adult years are often called continuing education. As such, they constitute the universe of formal LLI (actually lifelong education).

Informal learning - according to the Commission of the European Communities (2000)-is learning that "results from daily life activities related to work, family or leisure. It is not structured (in terms of learning objectives, learning time and/or learning support). Typically, it does not lead to certification. Informal learning. . . is non-intentional (or incidental/random)" (Colardyn and Bjornavold 2004, pp. 71). It can, thus, be regarded as a tacit form of learning through everyday activities. Coombs (1985) defined informal learning as "the spontaneous, unstructured learning that goes on daily in the home and neighbourhood, behind the school and on the play field, in the workplace, marketplace, library and museum, and through the various mass media, informal learning is by far the most prevalent form of adult learning" (p. 92)

In 2004, the Research Network on New Approaches to Lifelong Learning (NALL) carried out a telephone survey with a large representative national sample of the adul $(18+)$ Canadian population $(N=9,063)$ to provide quantitative detail on learning and work activities and their inter-relations. The survey confirmed that most adults detectable individual and collective learning is comparable to an iceberg; only $10 \%$ is visible at the surface, yet it is immense in its mostly submerged informal aspects (Livingstone 1999). The survey assessed participation in four aspects of informal learning: employment related, community volunteer work related, household work related and other general interest related. In each aspect, respondents were asked about informal learning activities on several specific themes. The questions used were developed to replicate the content of the Tough (1971) and Penland (1977) interview schedules, with appropriate revisions for changing circumstances (e.g. computer-based learning). The survey generated several interesting results. Notable was that older workers participated less in both adult education courses and in jobrelated informal learning. However, those not taking adult education courses remain quite active in job-related informal learning. Furthermore, most respondents felt that participating in formal course-based education and undertaking informal learning activities were complementary to each other.

While there is much research and data on formal LLL in the Netherlands and other countries (e.g. Wößmann and Schütz 2006; Bassanini et al. 2005), there is a dearth of reliable research and data on informal LLL and whether this learning is being used to its fullest potential in paid workplaces and beyond. The literature about LLL distinguishes several factors that might positively or negatively be related to informal LLL (see Bassanini et al. 2005 and Desmedt et al. 2006 for extensive overviews). Factors generally identified are:

- Personal traits: education level, age, family composition;

- Position on the labour market: working, without a job, inactive;

- Function characteristics: nature of the function, function level, part time job, temporary work
- Company characteristics: size, orientation on technological and social innovations, HRM policy;

- Sectoral system: unions, pension rights, funds for on-the-job education;

- Policy aspects: subsidies for education; fiscal arrangements that promote education, social security, minimal duration of formal education, formal education infrastructure;

- Supply of adult education: content, form, place, costs;

- Macro-economic development: economic growth, labour developments; tightness labour market.

While there is little research on the characteristics of those engaged in informal learning, there are a few noteworthy general characteristics of lifelong learners. Personal characteristics such as age or educational background have been found to influence engagement in informal learning (Berg and Chyung 2008). However, research on the relationship between age and informal learning is inconsistent. Tikkanen (2002), Livingstone and Stowe (2007) and Kremer (2005) show that less experienced, younger workers engage in more informal learning, while more experienced older workers view it as less embedded in their work. Therefore older workers are less likely to engage in informal learning activities. In contrast, Livingstone (1999) and Berg and Chyung (2008) find that older people engage as much in informal learning as younger people.

With regard to the association between the level of formal education and participation in informal learning activities, results of previous studies are also inconclusive. Livingstone (2007) found that with increasing educational attainment, the likelihood of participation in further education (formal as well as informal) increases. In contrast, Livingstone (2001) as well as Berg and Chyung (2008) found that the amount of time respondents spent on informal learning was about the same for all levels of education.

The relationship between individuals' engagement in informal learning activities and having a paid or unpaid job is not often subject of study. Livingstone (2007) and Livingstone and Stowe (2007) report that the employed labour force is slightly more inclined to undertake informal learning activities than unpaid volunteer or household workers. Hence, the age of individuals, their education level and their position on the labour market are variables of interest in explaining the amount of time spent on informal learning. We posit the following hypotheses:

1. The amount of time spent on informal learning increases as individuals are less mature (i.e. younger).

2. The amount of time spent on informal learning increases as individuals are more educated.

3. The amount of time spent on informal learning increases as individuals have jobs.

The question remains as to how the outcomes of informal learning were used in the learner's paid and/or unpaid work or in other contexts. Livingstone (1999) reported that the majority of studies focused on documenting the process of informal learning and the areas of learning. Very little is known about the actual outcomes 
that are perceived as resulting from informal learning activities (Livingstone 1999). Employability related research has shown that aspects of informal learning are related to employability dimensions (Van der Heijden et al. 2009; Van der Klink et al 2009). In these studies informal learning is operationalised as interaction with one' supervisor, the learning value of the job and networking opportunities. However, the studies are inconclusive about the informal learning aspects that are related to employability dimensions. Studies that use different samples report varied results.

The barriers people experience keeping them from engaging in learning activities were investigated by McCracken (2005). He categorised into two groups the factors that can be perceived as barriers to learning: intrinsic factors and extrinsic factors. Intrinsic factors are attributed to the individual's perception, motivation and emotions while extrinsic factors are associated with a person's external environment in terms of organisational culture, management development culture and physical resource factors. McCracken found the strongest barriers among managers that are "mid- career" (i.e. in their mid-thirties and forties) and who have attained a certain degree of experience in managerial jobs. While the study dealt with both formal and informal learning activities, it did not differentiate between them. In interviews with 22 managers, three distinct groups emerged, namely managers with mainly intrinsic issues, managers with mainly extrinsic issues and managers with both intrinsic and extrinsic issues. An important recommendation was to develop tailored development packages. The added value of our study lies in the fact that it focuses specifically on perceived barriers to informal learning.

\section{Methodology}

\section{Data Collection}

To determine how the amount of time individuals spend on informal learning varies with the characteristics of the individuals and of their position in the labour supply, we developed an on-line questionnaire which was distributed among an internet panel. This questionnaire was largely based on the telephone survey in the WALL-studies, but adapted to be used as an on-line questionnaire. It was also more focused on informal learning and was extended to question employability indicators (Van der Heijde and Van der Heijden 2006).

The questionnaire was distributed by an independent research agency making use of on-line research panels that are representative of the Dutch population. Respon dents received a small reward for participation, by means of participation points that can be exchanged for gift certificates. The agency made it possible to choose a sample based on geographic and/or demographic characteristics. The target respondents were Dutch citizens between 18 and 65 years old. A decision was made to include no more than $10 \%$ freelancers and $10 \%$ unemployed, since individuals in these categories are unable to answer most of the questions in our questionnaire; for instance questions about employability aspects.
To increase validity and reliability of the survey instrument, the questionnaire was reviewed by two academic experts on informal learning and one practitioner in human resource management, resulting in several adaptations of the exact wording and layout of items and response options. The data were collected during autumn 2009. The final questionnaire was administered via e-mail with a link to the on-line urvey to 800 Dutch citizens. Three e-mail invitations were returned as undeliverable. A total of 797 invitations were assumed to have reached the intended recipients. A total of 600 questionnaires were returned, of which 51 were incomplete. For each respondent the amount of time spent on answering the questions was noted, leading to elimination of 29 questionnaires, because the respondents had filled it in too quickly to be taken seriously. A total of 520 usable responses remained for analysis, resulting in an effective response rate $65.2 \%$, which was seen as very satisfactory for a survey of this length and kind (Kumar et al. 1995; Malhotra and Grover 1998). Complete anonymity was assured to reduce social desirability bias and to increase response rate.

An advantage of such an on-line questionnaire is that there are very little missing data. As foreseen, the most missing data were related to time spent on informal learning per week $(12.1 \%)$. This leaves us with 457 usable observations for all other questions.

\section{Sample Descriptives}

Descriptive data on demographic characteristics of our sample are presented in Table 7.1. Of the respondents, $59.5 \%$ were male and $40.5 \%$ female. Compared to the Dutch average of $54.3 \%$ male and $45.7 \%$ female in 2008 (data collected by the Central Bureau of Statistics) our sample has slightly more males and fewer females. At the time of the survey, $13.8 \%$ of the respondents held a doctoral or master degree as highest degree earned, $25.2 \%$ a (professional) bachelor degree, $11.2 \%$ a high school degree (senior level), $41.1 \%$ a secondary vocational degree (in $11.2 \%$ a high or "MAVO/MULO") and $8.8 \%$ a lower degree or no degree at all. Our sample is quite representative for the total Dutch labour force for which, respectively, the percentages are $11.6,21.1,8.1,34.8$ and 23.6. The average age of the respondents was 40 (Dutch average in the labour force is 39.9 years). Most respondents had average yearly wages of between 30,000 and $40,000 €$ in 2008 . For the total hutch labour force the average yearly wage is $33,400 €$ per year (data collected by the Central Bureau of Statistics).

\section{Measures}

The questionnaire contained demographic questions on age, sex, current job position, work experience and educational level. The dependent variable, time spent on informal learning, was measured with one item. After a brief explanation about the 
Table 7.1 Sample descriptives

\begin{tabular}{|c|c|c|c|c|c|}
\hline Continuous scale & N & Min & $\operatorname{Max}$ & $M$ & $S D$ \\
\hline Age & 457 & 18 & 64 & 40 & 11.65 \\
\hline No. of jobs in past 5 years & 450 & 1 & 5 & 2 & \\
\hline Family members & 457 & 1 & 7 & 3 & 1 \\
\hline Ordinal scale & & $\begin{array}{l}\text { No of } \\
\text { Categories }\end{array}$ & Min & Max & Mode \\
\hline $\begin{array}{l}\text { Education level (highest } \\
\text { diploma) }\end{array}$ & 457 & 15 & None & $\mathrm{PhD}$ & Secondary \\
\hline Yearly wages (euros) & 334 & 12 & 0 & $90,000-100,000$ & $30,000-40,000$ \\
\hline Dichotomous scale \% & & Yes & No & & \\
\hline Male & 457 & 59.5 & 40.5 & & \\
\hline Employed & 457 & 100 & 0 & & \\
\hline \multicolumn{6}{|c|}{ Job dynamics in past 5 years } \\
\hline First job acquired & 457 & 12.9 & 87.1 & & \\
\hline Promotion & 457 & 19.0 & 81.0 & & \\
\hline Changed jobs & 457 & 40.5 & 59.5 & & \\
\hline Became unemployed & 457 & 7.4 & 92.6 & & \\
\hline $\begin{array}{l}\text { Full-time to part time } \\
\text { employed/vice versa }\end{array}$ & 457 & 10.9 & 89.1 & & \\
\hline Maternity leave & 457 & 7.9 & 92.1 & & \\
\hline $\begin{array}{l}\text { None of the above } \\
\text { changes }\end{array}$ & 457 & 37.4 & 62.6 & & \\
\hline
\end{tabular}

definition of informal learning and a few examples, respondents were asked to in dicate the amount of hours per week that they spent on informal learning activities. Respondents were also asked to report the outcomes they perceive to be generated by the informal learning they undertook. Indicators of employability, such as subjective career-success and occupational expertise were used for this. Sujective career-success was measured with the measurement scales of Gattiker and Larwood (1986) on a 5-point Likert scale anchored by (1) "Strongly agree" to (5) "Strongly disagree". Sample items of the six items are: "I am drawing a high income compared to my peers", and "I am respected by my peers". Cronbach's alpha measure of internal consistency for these items is 0.729 . Occupational expertise (i.e. expertise needed to adequately perform the various job-related tasks and responsibilities) was measured as a construct variable, using 15 items from Van der Heijden et al. (2009) and Van der Heijde and Van der Heijden (2006). Occupational expertise was measured by 15 items on a 6-point Likert scale anchored by (1) "Does not apply at all" to (6) "Applies a great deal". The sample items are: "I consider myself competent to indicate when my knowledge is insufficient to perform a task or solve a problem", and "During the past year, I was in general competent to perform my work accurately and with few mistakes". Cronbach's alpha measure of internal consistency for these 15 items is 0.924 . The psychometric characteristics of the scales for subjective career success and occupational expertise were thoroughly investigated by Van der Heijde and Van der Heijden (2006). They indicated that both scales are valid and reliable.
Table 7.2 Means, standard deviations, and correlations

\begin{tabular}{lrrrrrrr}
\hline & Mean & \multicolumn{1}{l}{ SD } & \multicolumn{1}{c}{1} & 2 & 3 & 4 & 5 \\
\hline Informal learning & 5.26 & 8.43 & & & & & \\
Occupational expertise & 4.61 & 0.55 & -0.03 & & & & \\
Subjective career success & 3.36 & 0.52 & -0.02 & $0.23^{* *}$ & & & \\
Hours per week in paid job & 33.93 & 8.99 & 0.01 & $0.10^{*}$ & 0.03 & & \\
Agc & 40.60 & 10.72 & $-0.12^{*}$ & 0.04 & -0.05 & -0.07 & \\
Years of formal education & 11.54 & 2.85 & 0.09 & 0.07 & $0.16^{* *}$ & 0.07 & $-0.27^{* *}$ \\
\hline $\mathrm{N}=457$ & & & & & & & \\
${ }^{*} p<0.05 ;{ }^{* *} p<0.01$ & & & & & & &
\end{tabular}

In addition, barriers to informal learning were investigated in the survey using McCracken's (2005) classification. Intrinsic as well as extrinsic factors were studied. Following McCracken (2005) we define intrinsic factors as barriers to learning that are attributed to the individual's perception, motivation and emotions. Extrinsic factors are associated with a person's external environment, categorised as organisational culture, management development culture and physical resource factors. Respondents could tick boxes for all factors that they perceived to have hampered their informal learning.

\section{Data Analysis}

The first research question concerns the state of affairs of informal learning in the Netherlands; specifically, the relationship between the time spent on informal learning and background characteristics, including age, education level and number of working hours per week. This research question was developed into three hypotheses. We use descriptive statistics as well as a bivariate correlation between the individual's age and the time spent on informal learning to elaborate on hypothesis 1. Descriptive analysis as well as a non-parametric test is used to see whether the amount of time spent on informal learning is higher as individuals are better educated (hypothesis 2). Hypothesis 3 is addressed by calculating the bivariate correlation between hours worked per week and the amount of time spent on informal learning. We used descriptive statistics to report on how the outcomes of informal learning have been used in the learner's paid and/or unpaid work or in other contexts (research question 2). Descriptive statistics were also used to show the barriers that Dutch adults perceive as keeping them from engaging in informal learning (research question 3 ).

\section{Findings}

Table 7.2 reports the means, standard deviations and correlations between the most important variables. With respect to the dependent variable, people averaged 

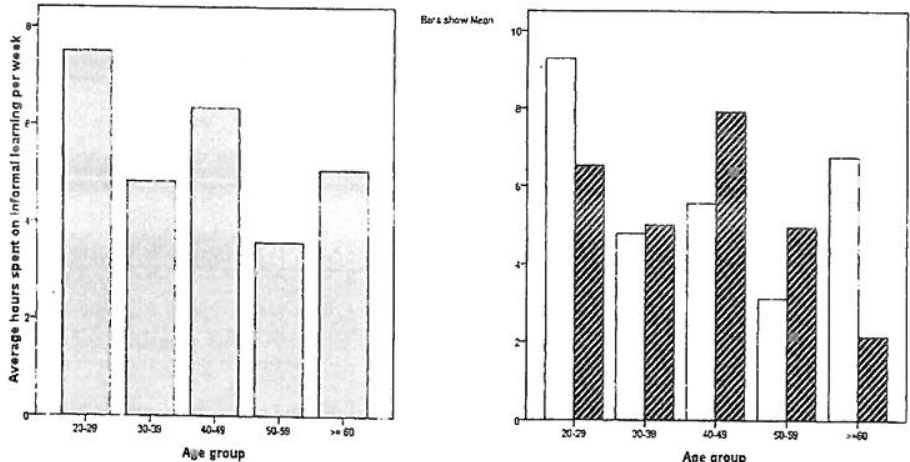

Fig. 7.1 Time spent on informal learning per age group

5.26 hours per week spent on informal learning. Note the negative correlation between age and hours spent on informal learning. The number of years of forma education is positively related to subjective career success and negatively related to age. We will revisit these results when discussing the hypotheses.

\section{Research Question 1: Relation Between Time Spent on Informal} Learning and Background Characteristics

Hypothesis I Hypothesis 1 posed that the amount of time spent on informal learning increases as individuals are less mature (i.e. younger). Our sample indicates that in the age groups 30-39 and 50-59 the fewest number of hours is spent on informal learning. Looking at sex differences, we see that the average amount of time spent per week on informal learning activities is high for males at the beginning of their professional career (i.e. between 20 and 29 years of age) as well as males in the final stage of their professional career (i.e. 0 yer than 60 years of age; Females are most engaged in informal learing when they are in years.

When a bivariate correlation was calculated between age and informal learning, a significant negative correlation was found (Pearson's $r=-0.117, p=0.006$ ), indicating that younger people spend more time on informal learning than older people.

Hypothesis 2 Hypothesis 2 posed that the amount of time spent on informal learning increases as individuals are more educated. Table 7.3 shows the average number of hours per week spent on informal learning by education level. Individuals with a middle-level secondary education are most engaged in informal learning activities $(52 \%)$. A second large group are those with a university bachelor degree $(25 \%)$.

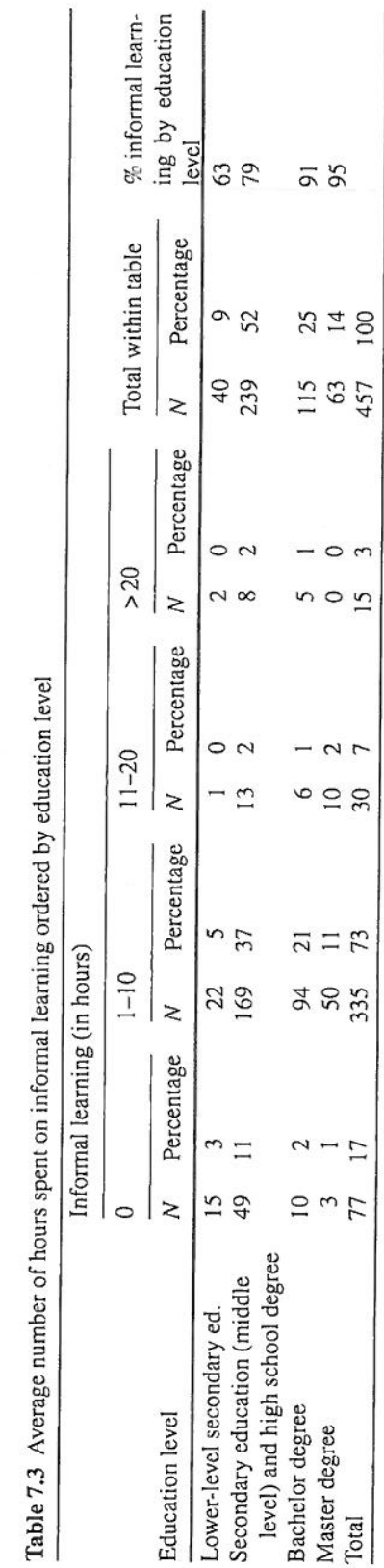


Table 7.4 Informal learning versus average paid hours worked per week, continuously employed Dutch Labour Force

\begin{tabular}{|c|c|c|c|c|c|c|c|c|c|c|}
\hline \multirow[t]{2}{*}{ Hours/week } & \multicolumn{10}{|c|}{ Informal learning } \\
\hline & 0 & & $1-10$ & & 11 & & $>21$ & & Total & \\
\hline $1-19$ & 7 & $2 \%$ & 23 & $5 \%$ & 2 & $0 \%$ & 0 & $0 \%$ & 32 & $7 \%$ \\
\hline 6) 29 & 17 & $4 \%$ & 54 & $12 \%$ & 4 & $1 \%$ & 3 & $1 \%$ & 78 & $17 \%$ \\
\hline 30-39 & 21 & $5 \%$ & 121 & $26 \%$ & 11 & $2 \%$ & 8 & $2 \%$ & 161 & $35 \%$ \\
\hline 40 & 23 & $5 \%$ & 112 & $25 \%$ & 10 & $2 \%$ & 2 & $0 \%$ & 147 & $32 \%$ \\
\hline $41-49$ & 2 & $0 \%$ & 14 & $3 \%$ & 2 & $0 \%$ & 2 & $0 \%$ & 20 & $4 \%$ \\
\hline$\geq 50$ & 5 & $1 \%$ & 7 & $2 \%$ & 0 & $0 \%$ & 0 & $0 \%$ & 12 & $3 \%$ \\
\hline Total & 77 & $17 \%$ & 335 & $73 \%$ & 30 & $7 \%$ & 15 & $3 \%$ & 457 & \\
\hline
\end{tabular}

Looking at the percentage of people with a certain education level engaged in informal learning, $95 \%$ of those with a master degree spend time on informal learning activities, while only $63 \%$ of those with lower-level secondary education do this. Table 7.3 also shows that $73 \%$ of the respondents report spending between 1 and 10 hours per week on informal learning. Only 3\% spend more than 21 hours per week. Bivariate correlation between years of formal education and informal learning indicated that the relationship is positive but weakly significant (Pearson's $r=-0.09$ $p=0.068$ ).

Our sample violates the normality assumption, hence one-way ANOVA could not be performed. Because of this, we used the non-parametric alternative, KruskasWallis test whose results show that groups of respondents with a different education level indeed differ significantly in their mean number of hours spent on informal learning (Chi-square $=26.475 ; p=0.000$ ). The lowest mean is found in the group with the lowest level secondary education and the highest mean by respondents with a master degree. This suggests that the level of education is positively related to the amount of time spent on informal learning.

Hypothesis 3 Hypothesis 3 posed that the amount of time spent on informal learning increases as individuals have jobs. Table 7.4 shows the distribution of time spent on informal learning activities. Note that we used identical intervals as those used by Livingstone and Stowe (2007). The largest category is constituted by people working between 30 and 40 hours who are engaged in 1-10 hours of informal learning per week. Bivariate correlation between hours worked per week and informal learning, yielded a nonsignificant and almost non existing relationship (Pearson's $r=-0.005$, $p=0.454)$. Kruskal-Wallis one-way ANOVA revealed nonsignificant differences in means between groups (Chi-square $=6.411 ; p=0.171$ ). Hence, we find no support for hypothesis 3 in our sample.

\section{Research Question 2: Outcomes of Informal Learning}

Descriptives Little research has been conducted on the perceived outcomes of informal learning. Table 7.5 shows what respondents indicated as outcomes generated by
Table 7.5 Outcomes of informal learning $(N=380)$

\begin{tabular}{|c|c|c|c|}
\hline Informal learning helps me to $\ldots$ & $\%$ & Informal learning helps me to $\ldots$ & $\%$ \\
\hline perform my job better & 80.3 & $\begin{array}{l}\text { acquire knowledge about job health } \\
\text { and safety aspects }\end{array}$ & 17.6 \\
\hline keep up with new knowledge & 72.9 & $\begin{array}{l}\text { acquire knowledge about labour con- } \\
\text { ditions and rights of employees }\end{array}$ & 15.5 \\
\hline perform new tasks in my job better & 56.8 & increase my income & 13.7 \\
\hline build computer skills & 44.7 & $\begin{array}{l}\text { increase my knowledge of foreign } \\
\text { languages }\end{array}$ & 11.8 \\
\hline $\begin{array}{l}\text { develop teamwork, problem solving } \\
\text { or communicative skills }\end{array}$ & 41.8 & get a promotion & 11.6 \\
\hline work with new machines & 32.4 & $\begin{array}{l}\text { further develop financial management } \\
\text { skills }\end{array}$ & 11.3 \\
\hline $\begin{array}{l}\text { further develop planning or manage- } \\
\text { ment skills }\end{array}$ & 25.8 & find a job & 6.1 \\
\hline $\begin{array}{l}\text { acquire insights into power structures } \\
\text { at work }\end{array}$ & 19.5 & keep my own business & 2.9 \\
\hline keep my job & 17.9 & Other & 7.4 \\
\hline
\end{tabular}

their informal learning. It shows how these outcomes have been used in paid and/or unpaid work or in other contexts. The majority indicates that informal learning helps them to do their job better and keep up with new knowledge in their area of expertise. With respect to the way in which employees use the outcomes of informal learning, $17.7 \%$ indicate that informal leaning is needed to keep their job, $13.7 \%$ indicate that it helps to increase income and $11.6 \%$ that it increases chances for promotion.

Correlation Analysis Career success (Van der Heijde and Van der Heijden 2006) and self-reported occupational expertise (Van der Heijden et al. 2009) can indicate a person's perceived career potential. We expect a positive relation between informal learning and career potential. However, bivariate correlation between informal learning and perceived career success yielded a negative nonsignificant correlation (Pearson's $r=-0.019, p=0.344$ ), indicating that informal learning is not perceived as being related to career success. This is also the case for informal learning and self-reported occupational expertise (Pearson's $r=-0.028, p=0.273$ ), indicating that people who spend much time on informal learning activities do not feel that they have much expertise. A possible reason is that may be precisely the people that feel that they have a lot to learn, and are not yet successful in their job, are the ones that engage most in informal learning activities

\section{Research Question 3: Barriers that Keep Dutch Adults from Engaging in Informal Learning}

The question remains why individuals choose not to engage in informal learning. What factors hamper informal learning in the perception of Dutch adults? Table 7.6 shows the barriers respondents perceived as keeping them from engaging in informal 
Table 7.6 Barriers to informal learning $(N=134)$

\begin{tabular}{lllc}
\hline Factor & $\%$ & Factor & $\%$ \\
\hline Lack of time & 61.2 & Activities take place in an unfriendly environment & 3.0 \\
Inconvenient time and place & 20.9 & Fear of failure & 2.2 \\
$\quad$ of activities & & & \\
Activities are ton expensive & 19.4 & No need for more education & 2.2 \\
Lack of emplojer support & 10.4 & Undertahing learning activittes is boring & 0.7 \\
Family responsibilities & 6.0 & Lack of availability of child care & 0 \\
Health problems & 3.7 & Other & 11.9 \\
\hline
\end{tabular}

learning. The main reasons are: lack of time $(61.2 \%)$, inconvenient time and place of informal learning activities (20.9\%) and cost $(19.4 \%)$. These three reasons ar categorised by McCracken (2005) as extrinsic factors that have to do with physical resource pressures. Apparently, individuals perceive the demands on themselves as very high. This causes time and resource pressures to impact their ability to devote time to informal learning activities. Typical intrinsic factors such as fear of failure and "don't need more education" were only reported by $2.2 \%$ of the respondents as hampering informal learning.

\section{Conclusion and Discussion}

This study investigated the Dutch population's perception about informal learning activities. The research was based on data from an on-line survey which yielded 520 qualified responses from Dutch citizens between 18 and 64 years old. We addressed key characteristics of the workforce including age, level of education and number of working hours per week and related these to the time spent on informal learning. In addition, we analysed the relationship between time spent on informal learning by employees and outcome measures, including subjective career success and occupational expertise. Finally, we presented data on the perceived barriers that keep people from engaging in informal learning.

The results of this study give an insight into the state of affairs of informal learning in the Dutch labour force. To summarise, the amount of time spent on informal learning increases as individuals are younger and more educated. There is no relationship between having a job and spending time on informal learning. The respondents did not perceive any specific job-related benefits from the time they spent on informal learning activities. Informal learning was not associated with perceived career success or with self-reported occupational expertise. Barriers to participation in informal learning activities stemmed mainly from extrinsic factors, such as lack of time, in convenience of LLL-activities with respect to time and place of the activities, cost of LLL-activities and lack of employer support.

The finding that younger people are more engaged in informal learning than older-more experienced people - is consistent with Tikkanen (2002) and Kreme (2005). This may be viewed as surprising, as it might seem logical that older people would be more interested in personal development that is not necessarily directly related to their work, for example, in the sphere of improving the quality of life in such areas as health, wealth and culture. Livingstone (1999) shows in this respect that older individuals tend to undertake more individual (rather than social) form of informal learning. However, our results might be due to the tendency Tikkanen noted that young people see working as learning. They feel that they need to gain experience in their job, and a large part of acquiring this experience induces informal learning activities, such as working alongside others, tackling new and challenging tasks (Eraut 2004), mentoring, coaching and networking (Cheetham and Chivers 2001; Marsick and Watkins 1990).

Other personal characteristics which influence informal learning are educational level and position in the labour market. Our research confirms that those with higher levels of formal education are more likely to participate (Brunello 2001; Desmedt et al. 2006; Livingstone and Stowe 2007). This can be explained by their recognising that every form of additional education gives a cumulative advantage to those with more education, while those with less education perceive additional education as bestowing fewer advantages (Wö $\beta$ mann and Schütz 2006). Moreover, informal learning might even carry social and psychological risks to lower educated individuals, since they might lose connection to their social class (Desmedt et al. 2006).

With regard to the link between hours worked per week and informal learning, we found no significant relationship in our sample. Note that the distribution of employment hours in the Netherlands is similar to the distribution in Canada, with 30 39 hours and 40 hours as two major groups. However, in Canada the group of people that worked $50+$ hours was substantial (19\% in 1998 and $25 \%$ in 2004), whereas in the Netherlands we find that only $3 \%$ of the people works more than 50 hours Our findings support Livingstone and Stowe (2007) who report that those who work fewer hours are no less reliant on job-related informal learning than full-timers. They only find weak associations between hours of paid work and participation in informal learning, and the relationship only holds for one particular time frame.

With regard to perceived benefits of time spent on informal learning activities, we found no positive association with perceived career success or self-reported occupational expertise. The cause for this might lie in the time lag between: (1) engaging in informal learning activities, (2) actual learning taking place and (3) experiencing career benefits from learning. It is likely that individuals who are highly engaged in informal learning, do so simply because they want to improve their career success and occupational expertise. Hence, they feel that these indicators are not yet at satisfactory level.

Barriers to participation in informal learning activities in our sample predominantly stemmed from extrinsic factors such as lack of time, inconvenience of time and place of LLL-activities, cost of LLL-activities and lack of employer support. This indicates that respondents feel that participation in informal learning activities must fit the responsibilities concerning work and family as well as other interests and obligations. In the questionnaire, respondents were told that informal learning is learning from daily life activities related to work, family or leisure which is not structured (in terms of learning objectives, learning time and/or learning support) 
Hence, it is actually not possible that there is not enough time, that the time and place is inconvenient and/or that the costs are too high. We feel, thus, that though this was explained, that they still interpreted informal learning as being tantamount to formal learning when asked about barriers encountered. This signals that the general population/labour force still does not recognise what informal LLL is and still sees LLI. as being something akin to lifelong or continuing education; that is something you do at a certain time and place.

An important managerial implication of these findings is that they generate a general awareness of the crucial input of informal learning for professional competence. Managers should be aware of the limitations of formal training programmes and acknowledge that much learning takes place in an informal way, for example, through observation and copying of senior, more experienced colleagues. It is important for organisations to focus on developing and stimulating learning skills in order to enhance informal learning and facilitate its taking place. Also human resource departments should be aware that when recruiting employees, it is important to assess their affinity to learning and find out whether they are willing to continuously improve (i.e. invest in) themselves. Furthermore, it is possible to help young inexperienced workers maximise their informal learning potential by placing them in a situation where there is much to learn. For example, an organisation could place "young potentials" in positions that provide post-qualification experience. In order to stimulate LLL, managers should encourage and create possibilities for employee to explore a wide variety of learning experiences including mentoring and coaching trajectories, sounding-board activities, external practice placements and working in collaborative team projects. As employees and their learning styles differ, personalised and flexible learning packages have a greater potential for encouraging and realising LLL than fixed, standardised trajectories. It is also important to help employees become self-directed learners, skilled at getting the best out of all learning opportunities available (see also Cheetham and Chivers 2001). External barriers to learning can be eliminated through fair reward strategies enabling managers to fully comprehend the value and reasons for LLL and development (see also McCracken 2005 , for additional ways of remedying barriers to learning).

Policy implications of this study lie in recognising that policy makers should consider how to best stimulate informal learning as an approach to positively impact LLL in the adult labour force in addition to formal educational initiatives currently employed. Furthermore, policy makers can be the driving force behind the development and implementation of systems that acknowledge experience, and informally acquired skills and qualifications gained by individuals. This could be of specia importance for local unemployment offices that try to assist unemployed workers in finding a job.

Though this research presents nothing less than a giant step in understanding the magnitude of participation of the Dutch labour force in LLL and the perceptions that they have related to informal LLL in the Netherlands, the major limitation is that it is purely descriptive and correlational. As such, it provides a basis for policy but also for further research that is more causal in nature. This will, in turn, lead to better decisions as to how LLL can be implemented and used for innovation, economic growth and social-cohesion, in conjunction with the transformation of Dutch production workers into knowledge workers. Further research, however, should adopt a methodology and approach which allows for regression analysis to provide more insight into the factors that stimulate LLL as well as the outcomes of LLL activities. Preferably, a research design should adopt a more in-depth longitudinal perspective. LLL activities as well as the perceived value of LLL and the barriers to it should be monitored over time. This approach could provide further insights into the changes in LLL behaviour of adults and how policy decisions and interventions affect it.

\section{References}

Bassanini, A., Booth, A., Brunello, G., De Paola, M., \& Leuven, E. (2005). Workplace training in Europe. IZA Discussion Paper No. 1640.

Berg, S., \& Chyung, S. (2008). Factors that influence informal learning in the workplace. Journal of Workplace Learning, 20(4), 229-244.

Bines, H. (1992). Issues in course design. In H. Bines \& D. Watson (Eds.), Developing professional education (pp. 11-27). Buckingham: Society for Research into Higher Education and Open University Press

Brunello, G. (2001). On the complementarity between education and training in Europe. IZA Discussion Paper No. 309.

CEDEFOP. (2009). European guidelines for validating non-formal and informal learning. Luxembourg: Office for official publications of the European Communities.

Cheetham, G., \& Chivers, G. (2000). A new look at competent professional practice. Journal of European Industrial Training, 24, 374-383.

Cheetham, G., \& Chivers, G. (2001). How professionals learn in practice! What the empirical research found. Journal of European Industrial Training, 25, 270-292.

Colardyn, D., \& Bjornavold, J. (2004). Validation of formal, non-formal and informal learning: policy and practices in EU Member States. European Journal of Education, 39(1), 70-88.

Commission of the European Communities. (2000). Commission staff working paper. A memorandum on lifelong learning. Brussels: European Commission.

Coombs, P. H. (1985). The World Crisis in Education: A View from the Eighties. New York: Oxford University Press.

Desmedt, E., Groenez, S., \& Van Den Broeck, G. (2006). Onderzoek naar de systeemkenmerken die de participatie aan levenslang leren in de EU-15 beinvloeden [Research on system characteristics influencing participation in lifelong learning in the EU-15]. Leuven: Katholieke Universitei Leuven.

Eraut, M. (2004). Informal learning in the workplace. Studies in Continuing Education, 26, 247 273

Faure, E., Herrera, F., Kaddoura, A., Lopes, H., Petrovsky, A., \& Rahnema, M. (1972). Learning to be. The world of education today and tomorrow. Paris: UNESCO.

Field, J. (2001). Lifelong education. International Journal of Lifelong Education, 20(1), 3-15. Gattiker, U., \& Larwood, L. (1986). Subjective career success: A study of managers and suppor personnel. Journal of Business and Psychology, 1, 78-94

Hagens, K., Van Den Hout, T., \& Kraaijvanger, H. (2007). OECD Thematic Review on recognition of non-formal and informal learning. Country Background Report for the Netherlands. Den Haag: Ministerie van Sociale Zaken en Werkgelegenheid.

Kremer, A. (2005). Predictors of participation in formal and informal workplace learning: Demographic, situational, motivational, and deterrent factors. Doctoral dissertation. Fairfax: George Mason University. 
Kumar, N., Sheer, L. K., \& Steenkamp, J. E. M. (1995). The effects of perceived interdependence on dealer attitudes. Journal of Marketing Research, 32, 348-356.

Livingstone, D. W. (1999). Exploring the icebergs of adult learning: Findings of the first Canadian survey of informal learning practices. Canadian Journal for the Study of Adult Education, 13(2), $49-72$.

Livingstone, D. W. (2001). Adults' informal learning: definitions, findings, gaps and future research Toronto: NALL Working Paper 21/2001. http://www.oise.utoronto.ca/depts/sese/csew/nall/res/ 21 adultsifnormallearning.htm. Accessed 30 Aug. 2003.

Livingstone, D. W. (2007). Re-exploring the icebergs of adult learning: Comparative findings of the 1998 and 2004 Canadian surveys of formal and informal learning practices. The Canadian Journal for the Study of Adult Education, 20(2), 1-24.

Livingstone, D. W., \& Stowe, S. (2007). Work time and learning activities of the continuously employed: A longitudinal analysis, 1998-2004. Journal of Workplace Learning, 19(1), 17-31.

Malhotra, M. K., \& Grover, V. (1998). An assessment of survey research in POM: from constructs to theory. Journal of Operations Management, 16, 407-425.

Marsick, V., \& Watkins, K. (1990). Informal and incidental learning in the workplace. New York: Routledge.

McCracken, M. (2005). Towards a typology of managerial barriers to learning. Journal of Management Development, 24, 559-575.

Penland, P. (1977). Self-planned learning in America. Pittsburgh: University of Pittsburgh.

Tikkanen, T. (2002). Learning at work in technology intensive environments. Journal of Workplace Learning, 14(3), 89-97.

Tissot, P. (2000). Glossary on identification, assessment and recognition of qualifications and competences and transparency and transferability of qualifications. In J. Bjornavold (Ed.), Making learning visible: Identification, assessment and recognition of non-formal learning in Europe. Luxembourg: Office for Official Publications of the European Communities.

Tissot, P. (2004). Terminology of vocational training policy: A multilingual glossary for an enlarged Europe. Luxembourg: Office for Official Publications of the European Communities.

Tough, A. (1971). The adult's learning projects. Toronto: OISE Press.

Van der Heijde C. M., \& Van der Heijden, B. I. J. M. (2006). A competence-based and multidimensional operationalization and measurement of employability. Human Resource Management, 45, 449-476.

Van der Heijden, B. I. J. M., Boon, J., Van der Klink, M., \& Meijs, E. (2009). Employability enhancement through formal and informal learning: An empirical study among Dutch nonacademic university staff members. International Journal of Training and Development, 13(1), $19-37$.

Van der Klink, M. R., Boon, J., \& Van der Heijden, B. I. J. M. (2009). The contribution of formal and informal learning to employability. The 23rd ICDE/EADTU World Conference, Maastricht, the Netherlands. Hosted by the Open Universiteit Nederland, 7-10 2009.

Van Merriënboer, J. J. G., Kirschner, P. A., Paas, F., Sloep, P. B., \& Caniëls, M. C. J. (2009). Towards an integrated approach for research on lifelong learning. Educational Technology Magazine, 49(3), 3-15.

Wößmann, L., \& Schütz G. (2006). Efficiency and equity in European education and training systems, Analytical Report for the European Commission. European Network on Economics of Education (EENEE) for the Communication and Staff Working Paper by the European Commission. [http://ec.europa.eu/education/policies/2010/back_gen_en.html]. Accessed 20 May 2010.

\section{Chapter 8 \\ Improving the Involvement of Higher Education Institutions in Learning and Innovation in a Regional Framework}

\author{
Herman van den Bosch and Marjolein Caniëls
}

\section{Introduction}

On many occasions, politicians as well as scientists warn that the leadership in economic development is shifting from western countries towards India, China and a selected group of South American countries. In spite of this, the European countries continue to be at the top of investments in science, and the scientific output (publications, patents) invariably belong to the world's best, although in some countries (for instance the Netherlands) the public investment in education is lagging behind. The fact that investments in academic research do not necessarily result in innovation is termed as "innovation paradox". Innovation is rooted in the search of agents for continuous improvement of their organization's core competences. Research in higher university institutions will only contribute to this goal if it reaches these agents. The general picture is that government, business and education lack alignment (Huijts 2003; Lagendijk and Rutten 2003; Nieuwenhuis et al. 2003; Storm 1986; Wetenschappelijke Raad voor het Regeringsbeleid 2008). Most European universities prefer research, for which the problem formulations result from debate between scientists and are therefore not connected to innovations in business or other organizations. Morgan (2007) is widely cited when he metaphorically refers to universities as "cathedrals in the desert".

Companies also have their share in the blame for the "innovation paradox". The willingness of companies to invest in long-term research programmes has disappeared in recent decades. The main cause is the emergence of shareholder value as a standard for business behaviour. The quest for a short-term return on investments limits the value of innovation to a more efficient production and to lower prices, instead of the development of new and better products (Dankbaar 2004).

H. van den Bosch (凶J) $\cdot$ M. Caniëls

Open University of the Netherlands, P.O. Box 2960, 6401 DL, Heerlen, The Netherlands

e-mail: herman.vandenbosch@ou.nl

M. Caniëls

e-mail·mariolein caniels@nu nl 